\title{
Zestawienie jako narzędzie dowodzenia w sportowych komentarzach prasowych
}

Celem artykułu jest zaprezentowanie, w jaki sposób dziennikarze sportowi wykorzystują zestawienia, wspierając dowodzenie swoich racji wygłaszanych w komentarzach prasowych. W badaniach wykorzystano przykłady wyekscerpowane z komentarzy publikowanych na łamach „Przeglądu Sportowego” w styczniu i lutym 2013 roku. Posłużą one jedynie jako materiał ilustracyjny, gdyż nie jest zamiarem autora sformułowanie wyczerpującej listy możliwych zastosowań retorycznych zestawienia.

Jakub Z. Lichański w pracy Retoryka. Historia - teoria - praktyka (2007) nazwał dowodzenie (argumentatio) „najważniejszą częścią mowy, której nigdy nie powinno zabraknąc"'. Wraz z refutatio tworzy ono trzon każdego wystąpienia. Umiejętne zaplanowanie argumentów, ich rozmieszczenie i wsparcie dowodami opartymi na retoryce lub niewykorzystującymi jej ma kluczowe znaczenie dla przekonania odbiorców o słuszności racji lub opinii nadawcy, oczywiście przy założeniu, że nie chodzi jedynie o zyskanie pozornej przewagi w dyskusji, a więc o posłużenie się chwytami erystycznymi, opisanymi m.in. przez Artura Schopenhauera².

W badaniach skupiłem się na dowodach odwołujących się do sztuki retorycznej. W rzeczywistości jest im nieco bliżej do erystyki, ponieważ na dalszy plan usuwają kwestie merytoryczne, a opierają się na emocjach, opiniach, wartościowaniu i rozumowaniach logicznych lub quasi-logicznych, mających na celu wywołanie przekonania o słuszności toku myślenia lub ocen prezentowanych przez autora danego tekstu. W połączeniu z odpowiednio dobraną

*Dr, e-mail: rafal.siekiera@onet.eu; Uniwersytet Łódzki, Wydział Filologiczny, Katedra Dziennikarstwa i Komunikacji Społecznej; 90-236 Łódź, ul. Pomorska 171/173.

${ }^{1}$ J.Z. Lichański, Retoryka. Historia - teoria - praktyka, t. 1: Historia i teoria retoryki, Wydawnictwo DiG, Warszawa 2007, s. 109.

${ }^{2}$ A. Schopenhauer, Erystyka, czyli sztuka prowadzenia sporów, przeł. J. Lorenowicz, Wydawnictwo Verso, Kraków 2006. Warto zauważyć, że nieco inne podejście do tego zagadnienia prezentuje Chaim Perelman (Imperium retoryki. Retoryka i argumentacja, przeł. M. Chomicz, Wydawnictwo Naukowe PWN, Warszawa 2004), który łączy klasyczną retorykę z teorią argumentacji. 
topiką dowodów, odwołaniami do różnych rodzajów modalności oraz specyficznym ukształtowaniem językowym czyni to ciągi dowodowe mniej lub bardziej skutecznymi, w zależności od sprawności nadawcy.

W literaturze tradycyjnie jako narzędzia dowodzenia wymieniane są: indukcja, dedukcja, sylogizm, entymemat czy epicheirēma. Warto jednak zwrócić uwagę na zestawienie, które - odpowiednio zastosowane - może stać się skuteczną bronią $\mathrm{w}$ dowodzeniu.

Zestawienie to termin, którego używam świadomie, unikając określenia „porównanie”, ponieważ interesuje mnie nie tylko tradycyjnie pojmowana figura, charakteryzująca się na poziomie językowym trójczłonową budową, z członem porównującym i porównywanym oraz funktorem jako dopełnieniem syntagmatycznym. Jest to tylko jedna z możliwych konceptualizacji językowych działania, którego dokonujemy w myślach. Językowa reprezentacja tej operacji mentalnej może mieć postać dłuższej wypowiedzi, przez co skupianie się tylko na reprezentacji o charakterze figury retorycznej (bądź tropu, jak chcą niektórzy), niepotrzebnie zawęża pole badawcze.

Dlatego też w swoich badaniach skupiam się na czymś, co Andrzej Kudra ${ }^{3}$ określa jako zestawienie-porównanie - bliskie definicji zaproponowanej przez Krzysztofa Szymanka, zgodnie z którą porównanie to „zestawienie dwóch rzeczy (osób, zjawisk itp.) w celu ukazania ich podobieństwa pod pewnym istotnym względem” lub „zestawienie dwóch lub większej liczby rzeczy (osób, zjawisk itp.) w celu ich scharakteryzowania poprzez ukazanie rozmaitych relacji między nimi - różnic, podobieństw, wzajemnych odniesień i powiązań”" . Tak rozumiane zestawienie zbliża się także do comparatio, będącego jednym z typów progymnasmatów.

Zestawiając dwa obiekty bądź zdarzenia, nadawca zwraca uwagę na ich podobieństwo bądź różnice między nimi. Niejednokrotnie jest to relacja dyskusyjna, a zastosowanie operacji zestawiania zyskuje charakter perswazyjny. Przekonanie odbiorcy o istnieniu podobieństwa między obiektami sprawia, że ich postrzeganie przez odbiorcę się zmienia. Porównanie wysuwa bowiem na pierwszy plan niektóre cechy przedmiotów - te mianowicie, które są im wspólne (są lub raczej wydają się wspólne). Sprawia to, że dobór członów w zestawieniu ma duże znaczenie. Jeśli zestawiamy kogoś z osobą powszechnie znaną, szanowaną bądź podziwianą i sugerujemy zachodzenie relacji podobieństwa, to liczymy na to, że, na zasadzie efektu „pławienia się w odbitym blasku”, pozytywne skojarzenia zostaną przeniesione na osobę porównywaną. Działa to oczywiście również w przypadku dążenia do zdeprecjonowania obiektu porównywanego - jako człon porównujący wybieramy wówczas obiekt posiadający negatywne konotacje.

${ }^{3}$ Zob. A. Kudra, Porównanie w poezji Stanisława Grochowiaka. Teoria chiralności i przyczynowości tropu, Wydawnictwo UŁ, Łódź 2004.

${ }^{4}$ K. Szymanek, Porównanie, [w:] tenże, Sztuka argumentacji. Stownik terminologiczny, Wydawnictwo Naukowe PWN, Warszawa 2008, s. 239. 
Perswazyjna siła zestawień polega także na ich obrazowości. Właściwy dobór zestawianych obiektów oraz środków językowych powoduje, że zwiększeniu ulega skuteczność argumentu. Mamy wówczas do czynienia z efektem unaocznienia tego, co nadawca próbuje wyrazić. Działa to tak, jakby postawiono oba obiekty przed oczami odbiorcy - wówczas łatwiej będzie mu dostrzec to, na co zwraca uwagę nadawca (szybciej dostrzeże podobieństwo lub kontrast, a wówczas jego uwaga skupi się na konkretnym zespole cech obiektu porównywanego). Poza tym w przypadku próby udowodnienia różnic zostaje uruchomiona zasada kontrastu - dwa różniące się od siebie przedmioty w bezpośrednim zestawieniu wydają się bardziej zróżnicowane niż w rzeczywistości.

Skuteczność perswazyjna zestawień opiera się również na wykorzystaniu potencjału asymetrii podobieństwa, polegającej na tym, że dwa obiekty uważamy za podobne do siebie nawzajem, jednak jeden z nich możemy postrzegać jako bardziej podobny do drugiego niż odwrotnie (podkreślam tu słowo „postrzegać”, bowiem z logicznego punktu widzenia podobieństwo jest symetryczne - o asymetrii podobieństwa pisał m. in. Amos Tversky ${ }^{5}$, podając przykład ojca i syna - mówi się, że ten drugi jest podobny do pierwszego, ale odwrotnie już nie). W zestawieniu-porównaniu odwołujemy się do obiektu, który jest nam (lub odbiorcy) bliższy poznawczo, aby uwydatnić pewne cechy innego, odleglejszego mentalnie obiektu. Dzięki temu odbiorca może łatwiej zrozumieć, co chce mu przekazać nadawca. Jeśli zaś zestawienie jest zaskakujące, nieoczekiwane, to komunikat w większym stopniu pobudza wyobraźnię odbiorcy. Efektem jest przyjęcie punktu widzenia autora tekstu i możliwość zrozumienia go. Jeśli odbiorca oceni zestawienie-porównanie jako trafne, to je zaakceptuje, a wraz z nim - sposób postrzegania danego przedmiotu. Zmiana sposobu postrzegania zaś jest jednym z celów działań perswazyjnych.

Manipulowanie sposobem postrzegania danego obiektu może wykorzystywać również obecne w zestawieniach zjawisko profilowania. Polega ono na uwypuklaniu pewnych cech przedmiotów, ludzi, zjawisk przy jednoczesnym zepchnięciu w cień innych $\operatorname{cech}^{6}$. Zestawienie ze sobą dwóch obiektów powoduje, że odbiorca ulega sugestii ich podobieństwa.

Tyle o zestawieniach-porównaniach i ich sile perswazyjnej, przejdźmy do komentarza prasowego. Zdaniem Barbary Bogołębskiej realizuje on funkcję

${ }^{5}$ A. Tversky, Cechy podobieństwa, przeł. R. Balas, [w:] Psychologia poznawcza w trzech ostatnich dekadach XX wieku, red. Z. Chlewiński, Gdańskie Wydawnictwo Psychologiczne, Gdańsk 2007, s. 521-557.

${ }^{6}$ Por. rozważania Magdaleny Zawisławskiej: ,,przez profilowanie rozumiem zatem zarówno uwydatnianie pewnych składników ramy interpretacyjnej, określenie ich konkretnych wartości, a także maskowanie pewnych elementów pojęciowych składających się na sytuację postrzegania" (taż, Czasowniki oznaczajace percepcję wzrokowa we współczesnej polszczyźnie. Ujęcie kognitywne, Wydział Polonistyki Uniwersytetu Warszawskiego, Warszawa 2004, s. 32). 
docere $^{7}$, a więc jednym z jego zadań jest pouczanie. Można zatem oczekiwać, że będzie w pewnym stopniu informatywny, ale także - spodziewać się rzetelności autora $\mathrm{w}$ argumentacji. Jak pisze Maria Wojtak,

w literaturze poświęconej gatunkom wypowiedzi dziennikarskich zalicza się komentarz do publicystyki, akcentuje aktualność poruszanych problemów, a także ich znaczenie dla określonego kręgu odbiorców. Zwraca się uwagę na subiektywność wywodu, interpretacyjny i perswazyjny charakter wypowiedzi, postuluje jasność i precyzję w wyrażaniu opinii .

Wspomniana przez autorkę subiektywność może się przejawiać m.in. w indywidualnym doborze argumentów, ale także w ukształtowaniu wywodu i przyjętym sposobie dowodzenia. Ponieważ zaś komentarze cechuje także perswazyjność, można się spodziewać, że autorzy będą sięgali po rozmaite środki, niekoniecznie realizujące funkcję docere (jeśli przyjąć, że jest ona dominantą funkcjonalną na poziomie gatunku, wówczas w badanym materiale powinniśmy się spodziewać przewagi dowodzeń opartych na argumentach pozajęzykowych, niewynikających ze sztuki retorycznej). W istocie teksty reprezentujące gatunek bywają realizacjami również innych funkcji związanych z perswazją, a więc zarówno movere, jak i delectare. Komentatorzy prasowi odwołują się bowiem nie tylko do dowodów logicznych (lub quasi-logicznych), lecz także emocjonalnych, łączących wartościowanie z modalnością oraz opierających się na szczególnym ukształtowaniu językowym (co stanowi pomost między argumentatio a elocutio).

Co interesujące, Michał Szulczewski wskazał na zestawieniowość komentarzy prasowych, uznając porównywanie za jeden z podstawowych sposobów organizacji treści w materiałach komentatorskich":

W zakresie sposobu przedstawiania problemu w komentarzu oraz wnioskowania wyodrębnić można następujące zasady czy warianty:

- dobór faktów: rozmieszczonych w czasie, rozmieszczonych w przestrzeni, rozmieszczonych w czasie i przestrzeni;

- zastosowanie przy charakterystyce: zasady podobieństw (przyrównywanie), zasady kontrastów (odróżnianie) $)^{10}$.

${ }^{7}$ B. Bogołębska, Między literatura i publicystyka, Wydawnictwo Piktor, Łódź 2006, s. 8.

${ }^{8}$ M. Wojtak, Gatunki prasowe, Wydawnictwo UMCS, Lublin 2004, s. 166. O komentarzu pisali także m.in.: J. Maziarski, P. Kurek, Z. Bauer, J. Fras, S. Bortnowski.

${ }^{9}$ Tak właśnie M. Szulczewski nazywał komentarz.

${ }^{10}$ M. Szulczewski, Publicystyka. Problemy teorii i praktyki, PWN, Warszawa 1976, s. 109. 
Zdaniem Szulczewskiego interpretowanie zdarzeń w komentarzu ma polegać na ukazywaniu ich powiązań z innymi zdarzeniami czy faktami. Doszukiwanie się zarówno podobieństw, jak i różnic może służyć dowodzeniu słuszności opinii komentatora bądź zastosowanej przez niego interpretacji zdarzeń. Odnalezienie właśnie takich przypadków zastosowania zestawień było celem przeprowadzonych badań. Jak się okazało, zebrany materiał dostarczył stosunkowo dużą ilość przykładów. Ponieważ celem niniejszego opracowania jest jedynie zarys zjawiska, nie zaś jego wyczerpujący przegląd, ograniczę się do zaprezentowania kilkunastu przypadków zastosowania zestawień-porównań w dowodzeniu.

Analiza zebranego materiału przeprowadzona została w oparciu o zaproponowaną przez Lichańskiego klasyfikację dowodzeń retorycznych ${ }^{11}$, na które składają się:

- dowody etyczne,

- dowody patetyczne,

- dowody logiczne (zwane też pragmatycznymi),

- dowody lączące modalność i wartościowanie.

Jak wykazało badanie, autorzy komentarzy w „Przeglądzie Sportowym” odwołują się do wszystkich wymienionych powyżej rodzajów dowodzeń, nadając im postać zarówno klasycznych porównań (wspomniane konstrukcje trójczłonowe), jak i obszerniejszych zestawień (w tym również kontrastywnych), obejmujących także wyliczanie przykładów.

\section{Dowody etyczne}

Są to te elementy argumentatio, które odwołują się do opinii i przekonań odnośnie do charakteru osób/zdarzeń, działań, dążeń. Wykorzystywanie takich argumentów może przyjąć formę powoływania się na opinię autorytetu, przy czym ów autorytet wcale nie musi być osobą powszechnie poważaną. Mamy wówczas do czynienia z odwróceniem kolejności - przywoływana osoba staje się autorytetem w oczach czytelników jedynie z racji tego, że dziennikarz w ogóle się na nią powołał (skoro autor artykułu cytuje kogoś takiego, oznacza to, że cytowany jest znawcą tematu).

Przykładem wykorzystania zestawienia w dowodzeniu etycznym jest komentarz Leszka Błażyńskiego Już nikt się nie śmieje:

\footnotetext{
${ }^{11}$ J. Lichański, dz. cyt., s. 110-111.
} 
Dobry żart primaaprilisowy. To chyba jakieś jaja! Tajner już nie ma innych pomysłów! Po co komu trzydniowy cyrk? - tak komentowano w środowisku narciarskim w poprzednim roku ideę organizacji konkursów Pucharu Świata na Stadionie Narodowym. [...] Zaledwie kilka miesięcy później inaczej już podchodzi się do nowatorskiego projektu. - Wy to macie pomysły - mówił mi wczoraj mistrz olimpijski z Lake Placid Toni Innauer i nie brzmiało to wcale tak, że głupi Polak z motyką porywa się na słońce. Znakomity przed laty zawodnik bardzo pozytywnie podszedł do przedsięwzięcia „skoki na Narodowym"12.

Autor komentarza próbuje udowodnić, że pomysł organizacji zawodów w skokach narciarskich na Stadionie Narodowym nie jest wcale niedorzeczny i może zostać wprowadzony w życie. W tym celu wykorzystuje dowodzenie etyczne, odnoszące się do opinii innych ludzi, i tworzy zestawienie kontrastywne - prezentuje negatywne oceny pomysłu, jakie funkcjonowały w środowisku rok wcześniej oraz zmienione aktualne podejście. Porównanie wykazuje zmianę w opiniach o omawianej idei, co ma być wyraźnym dowodem, że pomysł nie jest zły i jego realizacja jest możliwa (sugestia, że jeszcze rok wcześniej nikt nie wierzył w powodzenie takiego przedsięwzięcia, a teraz nagle krytycy zmieniają zdanie, uwiarygodnia twierdzenie dziennikarza, że konkurs Pucharu Świata w skokach narciarskich na Stadionie Narodowym może się odbyć). Powołując się na słowa Toniego Innauera, byłego skoczka narciarskiego, autor kreuje jego autorytet w dziedzinie organizacji zawodów sportowych - kreuje, ponieważ mamy tu do czynienia z autorytetem sztucznie wytworzonym. Były skoczek narciarski niekoniecznie musi znać się na organizowaniu konkursów Pucharu Świata, na logistyce i zasadach konstruowania skoczni narciarskich. Powołanie się na jego opinię ma jednak w założeniu wzmocnić przekaz zawarty w zestawieniu - dziś nawet byli mistrzowie olimpijscy popierają pomysł ${ }^{13}$.

Innym przykładem zastosowania zestawienia jako narzędzia dowodzenia etycznego jest komentarz Bożydara Iwanowa dotyczący zbliżającego się meczu reprezentacji Polski w piłce nożnej: „Selekcjoner [Waldemar Fornalik] dba o hierarchię w drużynie, w decyzjach personalnych stara się być do bólu konsekwentny i sprawiedliwy, jego wyjściowy skład jest niemal tak samo łatwy do przewidzenia jak u Jerzego Engela"14. Autor przekonuje, że nie należy spodziewać się niespodzianek w składzie reprezentacji w nadchodzącym meczu i argumentuje to tym, że Fornalik jest bardzo konsekwentny - posiłkuje się porównaniem do innego selekcjonera, Engela, znanego z niezmieniania składu. W tym przypadku zatem zestawiane są nawyki obu szkoleniowców. By udowodnić słuszność

${ }^{12}$ L. Błażyński, Już nikt się nie śmieje, „Przegląd Sportowy” 2013, 29.01, s. 10.

${ }^{13}$ Warto zauważyć, że T. Innauer w cytowanej wypowiedzi wcale pomysłu nie popiera, a czytelnik dysponuje jedynie zapewnieniem autora, że słowa byłego skoczka nie brzmiały drwiąco.

${ }^{14}$ B. Iwanow, [brak tytułu], „Przegląd Sportowy” 2013, 5.02, s. 2. 
tezy, dziennikarz wskazuje, że Fornalik z zasady nie zmienia składu, ponieważ taki już jest. Trudno więc się spodziewać, że trener nagle się zmieni i postanowi powołać kilku nowych zawodników. Taki argument, wsparty porównaniem do powszechnie znanego z konsekwencji byłego selekcjonera, trudno jest podważyć. Zestawienie jest tutaj wykorzystane jako sposób na objaśnienie zjawiska mało znanego (Fornalik był wówczas trenerem kadry narodowej od kilku miesięcy, więc jego nawyki były kibicom obce) za pomocą zjawiska znanego i zrozumiałego. Taki zabieg daje odbiorcom konkretne wyobrażenie o zasadach, jakimi kieruje się nowy selekcjoner, ponieważ coś podobnego już widzieli - w czasach, gdy reprezentację prowadził wspomniany Jerzy Engel.

Dowodzenie etyczne dziennikarze sportowi niekiedy łączą z modalnością, co ma zwiększyć skuteczność fazy argumentatio ich tekstów. Tak jest chociażby w poniższym przykładzie:

To będzie rok pod znakiem piłkarskiej reprezentacji Polski. [...] Albo będziemy piać z zachwytu, albo będziemy ekipę Waldemara Fornalika surowo rozliczać. Trzecią możliwość trudno sobie wyobrazić, bo popadanie ze skrajności w skrajność - od zachwytu po totalne rozczarowanie - to nasza specjalność. W minionym roku właśnie taką narodową miarą potraktowaliśmy drużynę Franciszka Smudy. Kibice i media tak się po nim przejechały, że chłop do dzisiaj nie może się pozbierać. Pewnie, że zasłużył, bo wiedział, w co się pakuje. Miało być wyjście z grupy na wyjątkowo naszych mistrzostwach Europy, a nie było. [...] A teraz ma być awans do finałów mistrzostw świata - zadanie pewnie trudniejsze niż w przypadku EURO $2012^{15}$.

Autor przekonuje, że kadra Fornalika będzie surowo rozliczana. W tym celu przywołuje przykład kadry Smudy i sugeruje, że Fornalika spotka taki sam los, co jego poprzednika, bo ma trudniejsze zadanie. Wykorzystanie dowodzenia etycznego polega w tym przypadku na odniesieniu do polskiej mentalności. Prezentowanie skrajnych postaw (zwłaszcza wobec selekcjonerów piłkarskiej reprezentacji Polski) komentator uważa za specjalność Polaków. Zatem autor narzuca czytelnikom następujący tok rozumowania: ponieważ polskich kibiców cechuje skłonność do popadania ze skrajności w skrajność (jest to stała cecha ich charakteru), o czym przekonał się Smuda, który początkowo uważany był za zbawcę, a odchodził w ogniu krytyki, to Fornalik na koniec roku może być tylko wychwalany lub ostro krytykowany. W tym miejscu jeszcze nie ma wyraźnego stwierdzenia, że obecny selekcjoner spotka się z falą krytyki. Dopiero kolejne zestawienie - zadania, jakie stoi przed Fornalikiem i celu, jaki miał Smuda ujawnia nieuchronność losu trenera kadry. Autor wskazuje, że awans na mistrzostwa świata w Brazylii będzie trudniejszy niż wyjście z grupy na mistrzostwach

${ }^{15}$ A. Bugajski, Noworoczny plan dla kadry, „Przegląd Sportowy” 2013, 2.01, s. 14. 
Europy. Skoro reprezentacja nie podołała teoretycznie łatwiejszemu zadaniu, to dlaczego miałaby poradzić sobie z trudniejszym?

W powyższym fragmencie dowód etyczny łączy się z modalnością aleatyczną ${ }^{16}$ - Antoni Bugajski stwierdza, że jedno $\mathrm{z}$ dwóch przedstawionych przez niego rozwiązań jest konieczne i innej możliwości nie ma (,trzecią możliwość trudno sobie wyobrazić"). Skoro zaś z zestawienia zadań, jakie mieli do wykonania obaj selekcjonerzy, wynika, że Fornalik jest w trudniejszej sytuacji niż jego poprzednik, to owa konieczność nieuchronnie dotyczyć musi nadchodzącej fali krytyki wobec obecnego trenera.

Takie połączenie dowodzenia etycznego z modalnością zwiększa skuteczność wywodu - czytelnikowi trudno jest zanegować tok rozumowania autora, który powołuje się zarówno na przykłady z przeszłości (porównując je z obecną sytuacją), jak i cechy charakterystyczne osób bądź całych grup (tu grupą byli polscy kibice). Sprzeciwić się można jedynie autorskiej ocenie skali trudności celów, co Bugajski nieco maskuje kolejną modalnością - wprowadzając przypuszczenie (,awans do finałów mistrzostw świata - zadanie pewnie [podkreśl. - R.S.] trudniejsze") i broniąc się w ten sposób przed ewentualnym zarzutem czarnowidztwa.

$\mathrm{W}$ analizowanym materiale dowody etyczne łączą się także z pragmatycznymi, tworząc rozumowania oparte zarówno na opiniach, jak i trudnym do odrzucenia dowodzeniu logicznym, próbującym wytworzyć niepodważalną wiarygodność autora:

[...] na Zygmunta Solorza, posiadacza 51 procent udziałów w klubie, manewry miasta z Karkosikiem wcale nie muszą działać uspokajająco. Tak się składa, że on do tej pory z władzami Wrocławia nie umiał zrobić dobrego dla siebie interesu. Chciał zarabiać na stadionowych lożach, Dutkiewicz mu nie pozwolił. Wpadł na pomysł, by jego firma została operatorem Stadionu Miejskiego i znowu usłyszał stanowcze „nie”. I najważniejsze: chciał wybudować galerię handlową przy stadionie, ale nie dostał korzystnego kredytu, a prezydent na jego kłopoty tylko wzruszył ramionami. Dlatego Solorz ma już dość Śląska $[\ldots]^{17}$.

Dziennikarz udowadnia, że planowane wejście do klubu nowego sponsora, prowadzącego właśnie rozmowy na ten temat z władzami Wrocławia, wcale nie musi być dobrą wiadomością dla największego udziałowca klubu, Zygmunta Solorza. W tym celu autor zestawia plany Wrocławia $\mathrm{z}$ dotychczasowymi przedsięwzięciami, które się nie powiodły (z punktu widzenia Solorza). Jest to zestawienie tworzące dowód logiczny oparty na myśleniu indukcyjnym: skoro dotychczas żaden interes z miastem nie skończył się dla przedsiębiorcy dobrze, to tym razem

16 J. Lichański, dz. cyt., s. 111.

${ }^{17}$ A. Bugajski, Mistrz Polski utknąt w dziurze, „Przegląd Sportowy” 2013, 4.01, s. 2. 
najprawdopodobniej będzie tak samo, więc biznesmen nie ma powodów do optymizmu. Jednocześnie Bugajski wykorzystuje w tym fragmencie dowód etyczny, odnoszący się do powszechnej wiedzy o działaniach Solorza i władz Wrocławia charakter ich wzajemnej relacji (każdy próbuje działać wyłącznie na swoją korzyść) powoduje, że wspólne przedsięwzięcia związane z klubem nigdy się nie udają.

\section{Dowody patetyczne}

Jest to grupa dowodów wywołujących w odbiorcach określone emocje, ułatwiające przyjęcie argumentacji nadawcy. Ich istotą jest blokowanie chęci weryfikacji twierdzeń mówcy. Dowodów patetycznych możemy się więc spodziewać w sytuacjach, gdy nadawca nie ma wystarczająco silnych argumentów pozaretorycznych i logicznych.

$\mathrm{Z}$ taką sytuacją mamy do czynienia w poniższym fragmencie komentarza Rafała Susia:

We Wrocławiu to dopiero mają dobry scenariusz! Zanosi się na to, że nowy stadion będą remontować, zanim zakończy się ostatecznie jego budowa. Wtedy osiągną mistrzostwo. Do tej pory w Polsce takimi wyczynami mogli pochwalić się (znowu zresztą od wczoraj na tapecie) - drogowcy. Jeszcze asfaltu kłaść nie skończyli, a już trzeba było łatać dziury na początku budowanej jezdni. Cóż, nie bez powodu nasz rdzennie polski żart głosi: roboty na budowie było tak dużo, że nie było czasu taczek ladować ${ }^{18}$.

Celem artykułu jest udowodnienie, że polskim sportem narodowym jest partaczenie budownictwa (,Tak, budowanie czegokolwiek, czyli partaczenie, przyzwolenie na bylejakość, przymykanie oka, branie pod stołem, na szybko i po łebkach - to okazuje się jest nasz sport narodowy!"19). W tym celu zostaje wykorzystany przykład budowanego we Wrocławiu stadionu, który wymaga remontu jeszcze przed ukończeniem budowy. Komentator nie powołuje się jednak na rzeczowe argumenty i nie stara się zagłębić w przyczynę problemu (czytelnik nie wie, co konkretnie wymaga naprawy, ani jakie są tego powody). Całą winą obarcza ekipę budowlaną, którą porównuje z cieszącymi się w Polsce złą sławą (i wzbudzającymi negatywne emocje) drogowcami. W ten sposób ośmiesza budowniczych stadionu i jednocześnie sprawia, że niechęć związana z drogowcami przenosi się na budowlańców.

\footnotetext{
${ }^{18}$ R. Suś, Nasza narodowa dyscyplina, „Przegląd Sportowy” 2013, 31.01, s. 2.

19 Tamże.
} 
Przykładem nieco innego wykorzystania zestawienia w dowodzeniu patetycznym jest fragment komentarza Pawła Burlewicza:

Przyznam się, że drżałem wczoraj, obserwując pogoń najgroźniejszych rywalek za Justyną Kowalczyk. Bałem się tego, co potrafi norweski tir. Potężna, świetnie wyposażona ciężarówka. I nie zamierzam tu absolutnie bawić się $\mathrm{w}$ grę obraźliwych półsłówek, jak Petter Northug wypowiadający się o naszej liderce. Mam na myśli sprzęt Norwegów, przewożony w imponującym pojeździe. Bo taka kuriozalna trasa, jak bieg w dół z Cortiny d'Ampezzo do Toblach, zmienia się w rywalizację serwismenów i trenerów ${ }^{20}$.

Porównanie użyte zostało w sposób nietypowy - dla odróżnienia autora od biegacza norweskiego i zasugerowania w ten sposób, że wypowiedź dziennikarza stoi na wyższym poziomie oraz ma wartość merytoryczną (w przeciwieństwie do słów Northuga, które były po prostu „grą obraźliwych półsłówek”). Jest to zestawienie wprowadzające dowód patetyczny, odwołujący się do emocji i wartościowania. Autor komentarza w pewnym sensie informuje odbiorców: moje słowa zawieraja merytoryczne argumenty, a jego - sq obraźliwe. Dzięki temu dalsze opinie dotyczące biegu mają zyskać walor merytorycznej oceny, a nie przepychanek słownych. Porównanie pełni więc funkcję pomocniczą wobec głównego wywodu, wzmacniając jego wiarygodność.

Dowodzenie patetyczne, podobnie jak etyczne, bywa łączone z logicznym. Tak jest, dla przykładu, w komentarzu Grzegorza Rudynka, oceniającego zapowiadany transfer piłkarza Roberta Lewandowskiego:

Jeśli [...] okaże się to prawdą, oznacza to nowy rozdział w nowożytnej erze polskiego futbolu. W końcu Polak ma szansę trafić do klubu z najwyższej półki, by odgrywać w nim pierwszoplanową rolę. To nie jest przejście Jerzego Dudka do Liverpoolu, klubu legendarnego, ale lata świetności mającego za sobą [...]. To jest także inna kategoria niż angaż Dudka w Realu Madryt, w którym z góry skazany był na rolę rezerwowego Ikera Casillasa. [...] Ponoć transakcja opiewać będzie na 25 mln euro. Kwota astronomiczna. Dotychczasowy rekord transferu polskiego piłkarza może zostać pobity ponad trzykrotnie (za Dudka Liverpool zapłacił Feyenoordowi ok. 7 milionów euro) ${ }^{21}$.

Właściwie powyższy cytat stanowi przykład dowodu logicznego, który jest jednocześnie patetyczny. Odwołanie do logiki to porównanie sportowego aspektu spodziewanego transferu z zakupem Dudka przez Liverpool, a potem - Real

20 P. Burlewicz, Groźna ciężarówka, „Przegląd Sportowy” 2013, 4.01, s. 16.

${ }^{21}$ G. Rudynek, Gdy Niemiec powie o stowo za dużo, „Przegląd Sportowy” 2013, 12.02, s. 2. 
Madryt. W przypadku bramkarza najpierw był transfer do klubu słabszego niż w przypadku transferu Lewandowskiego (zatem, logicznie myśląc, zdaje się sugerować autor - transakcja z udziałem Lewandowskiego jest ważniejszym wydarzeniem), a potem - co prawda do lepszego, ale tam z kolei Dudek był tylko zmiennikiem podstawowego bramkarza (tymczasem spodziewano się, że Lewandowski będzie odgrywał ważniejszą rolę w swoim nowym klubie). Zarówno logika, jak i emocje (a więc dowód patetyczny) wiążą się z porównaniem spodziewanej kwoty transferu z kwotą transferu Dudka - wskazanie, że polski piłkarz będzie kosztował 25 milionów euro, ma wzbudzić emocje - przede wszystkim podziw i poczucie dumy. Dzięki temu potwierdzi się opinia autora, że transfer Lewandowskiego będzie najważniejszy w historii polskiego futbolu.

\section{Dowody logiczne}

Jest to najliczniej reprezentowana w materiale badawczym grupa dowodów posługujących się zestawieniami. Dowodzenie logiczne, zwane też pragmatycznym, opiera swoją siłę na wiarygodności rozważań logicznych ${ }^{22}$ (bądź quasi-logicznych). Szkicowy charakter niniejszego opracowania nie pozwala na przytoczenie wszystkich przypadków użycia zestawień w dowodzeniach logicznych, dlatego ograniczę się do zaprezentowania kilku spośród nich:

Szkoda, że w Val Münster Justyna Kowalczyk nie weszła do finału sprintu stylem dowolnym. [...] Wydaje mi się, że Kikkan Randall była nie do pokonania. Ale już o podium Justyna mogła powalczyć. I tak jednak nie ma co narzekać, bo generalnie sytuacja naszej biegaczki jest bardzo dobra. Poza tym, Randall w klasyfikacji generalnej się nie liczy, a Justyna powiększyła przewagę nad Therese Johaug, a to najważniejsze ${ }^{23}$.

Autor próbuje przekonać, że wynik Justyny Kowalczyk nie był najgorszy, a porażka z Kikkan Randall (USA) nie ma znaczenia, bo ważniejsza jest pozycja w klasyfikacji generalnej, a w tej Amerykanka w ogóle się nie liczy. Mimo że Kowalczyk nie wygrała, i tak osiągnięty wynik pozwolił jej zwiększyć przewagę nad ważniejszą rywalką - Therese Johaug. Dziennikarz opiera dowodzenie na trudnym do podważenia rozumowaniu: klasyfikacja generalna Pucharu Świata jest najważniejsza; skoro Randall się w niej nie liczy, a Kowalczyk ma bardzo dobrą pozycję, to porażka $\mathrm{z}$ Randall jest nieistotna i nie powinna martwić kibiców (jest to zatem zestawienie, które spełnia funkcję sylogizmu).

22 Dowody takie wykorzystują m.in. ciągi indukcyjne, dedukcję, sylogizmy, entymematy.

23 J. Łuszczek, [brak tytułu], „Przegląd Sportowy” 2013, 2.01, s. 2. 
W kolejnym przykładzie również pojawia się sylogizm, a zestawienie tym razem pełni funkcję pomocniczą wobec niego:

A teraz ma być awans do finałów mistrzostw świata - zadanie pewnie trudniejsze niż w przypadku EURO 2012. Bo kalendarz tak sobie ułożyliśmy, że na koniec gramy na wyjazdach z Ukrainą i Anglią. Z Anglikami zwycięski wyjazdowy remis na koniec kwalifikacji mieliśmy równo 40 lat temu. A potem, co wizyta na wyspach, to porażka. Jeżeli więc gdzieś był przypadek, to właśnie w 1973 roku. Trzeba więc zrobić wszystko, by mecz z Anglią już nie mógł mieć dla Polski złych konsekwencji - tak jak nie miał w 2005 roku za kadencji Pawła Janasa ${ }^{24}$.

Jest to dalszy fragment cytowanego już wcześniej komentarza Bugajskiego, analizującego sytuację wyjściową reprezentacji w piłce nożnej w roku 2013. Autor przekonuje, że nie wolno nastawiać się na mecze z Ukrainą i Anglią jako rozstrzygające kwestię awansu i należy spróbować zapewnić sobie kwalifikację na mundial jeszcze przed tymi spotkaniami. Komentator, odwołując się do przeszłości, porównuje obecną sytuację z tą z 2005 roku - wówczas porażka z Anglią na koniec eliminacji nie miała znaczenia, teraz już będzie miała, więc trzeba zrobić wszystko, żeby tego uniknąć. Właśnie w tej części wywodu pojawia się sylogizm: większość meczów z Anglią na koniec eliminacji przegraliśmy, skoro więc teraz znów gramy z Anglią na koniec, to pewnie przegramy - i tu porównanie $\mathrm{z}$ kadrą Pawła Janasa zostaje zastosowane jako wskazówka, co należy zrobić - Janas postarał się w innych meczach, aby ewentualna porażka z Anglią nie miała już znaczenia. Kibice piłki nożnej wiedzą, że kadrze z 2005 roku udało się awansować do mistrzostw, mimo że przegrała w ostatnim meczu z Anglią 1:2.

W badanym materiale znalazły się także przykłady zastosowania zestawień w funkcji rozumowań indukcyjnych. Oto jeden z takich przypadków:

Oburzają się kibice Polonii, że Ireneusz Król rozpoczął demontaż kadrowy drużyny. [...] Patrzę na sprawę chłodniej. Konkretne przykłady pokazują, że osłabienia nie muszą wcale oznaczać sportowej degrengolady. Paradoksalnie, stają się polską tradycją. [...] Król się rozochocił. Zobaczył, że w polskiej lidze można przytanić, nawet pójść w owym przytanianiu po bandzie, i nie musi odbić się to na poziomie. Szlak miał przetarty - mistrzem w takiej strategii okazał się Sylwester Cacek. W Widzewie ciął koszty od dawna [...], a kilka miesięcy temu [...] na funkcji prezesa obsadził Monikę Miłkowską-Bruczko, biegłego rewidenta. Za zadanie miała optymalizować koszty, jak to ładnie mówią pracodawcy, czyli ciąć. Dzieło skończyła i odeszła. Efekt jest taki, że na poziomie drużyny nie za bardzo te wszystkie operacje się odbijają. [...] Zdaje się, że Król obrał tę właśnie drogę. I przy okazji promuje siebie.

\footnotetext{
${ }^{24}$ A. Bugajski, Noworoczny plan...
} 
W komentarzu dziennikarz staje na stanowisku, że oszczędzanie oparte na sprzedaży najlepszych zawodników i zastępowaniu ich polską młodzieżą nie musi oznaczać obniżenia poziomu zespołu Polonii Warszawa (i jednocześnie stawia tezę, że staje się to polską tradycją). Dowodem ma być zestawienie warszawskiego klubu z Widzewem Łódź. Skoro Sylwestrowi Cackowi udało się zmniejszyć koszty przez pozbycie się najlepiej zarabiających zawodników, a drużyna nie gra słabiej, to tak samo może być w przypadku Polonii. Takie postawienie sprawy to $\mathrm{w}$ istocie quasi-indukcja. Autor próbuje przekonać odbiorców do swoich racji, powołując się na zaledwie jeden przypadek. Czytelnik ma uwierzyć, że jeśli pewne działanie udało się raz, to uda się również ponownie. Tymczasem poprawna indukcja wymagałaby przytoczenia kilku przykładów, co i tak nie owocowałoby pewnością, a jedynie jej pozorami ${ }^{25}$.

Na koniec rozważań warto przytoczyć jeszcze dwa ciekawe przypadki wykorzystania zestawień. W pierwszym z nich operacja porównywania owocuje interesującym połączeniem dowodzenia $\mathrm{z}$ fazą refutatio:

To mogą być niezwykle trudne mistrzostwa dla Justyny Kowalczyk. Mimo że nie ma kłopotów ze zdrowiem jak w 2007 r. w Sapporo. Mimo że pewnie nie popełni takiego błędu jak w Libercu w 2009 r., gdy nadmierne zdenerwowanie sprawiło, że zmarnowała szansę na złoto na $10 \mathrm{~km}$ stylem klasycznym. Mimo że Marit Bjoergen nie osiągnęła aż tak oszałamiającej formy, jak w Oslo dwa lata temu. Wszystko z powodu postępującej specjalizacji².

Porównania do zawodów sprzed lat są w istocie wyprzedzaniem ewentualnych argumentów przeciwników - autor przytacza je wszystkie i stwierdza, że mimo to Kowalczyk będzie trudniej (choć na logikę wydawałoby się, że powinno być łatwiej), po czym wysuwa własny argument, który ma być potwierdzeniem tezy: w biegach narciarskich coraz więcej zawodniczek specjalizuje się w poszczególnych konkurencjach, a Polka jest wszechstronna, co na mistrzostwach utrudnia jej zadanie (skupia się na kilku startach, podczas gdy każda jej rywalka przygotowuje się na jeden lub dwa). Za pomocą zestawienia (które jest niejako sięgnięciem po „bron” adwersarzy i pomostem między refutatio a argumentatio) autor wzmacnia swój argument, odwołując się do logicznego myślenia tylko po to, żeby podkreślić, że mimo wszelkiej logiki, Kowalczyk będzie miała trudne zadanie (wykazuje nieaktualność logicznego rozumowania, zatem byłoby to coś w rodzaju dowodu wbrew logice).

Ostatni przykład to wsparcie dowodzenia poprzez zastosowanie porównań w sferze elocutio:

${ }^{25}$ Pewność daje indukcja matematyczna.

${ }^{26}$ P. Burlewicz, Będzie trudno jak nigdy, „Przegląd Sportowy” 2013, 20.02, s. 14. 
Myślałem, że wpadka dopingowa Mariusza Wacha to początek i koniec dziwnych historii związanych z naszym bokserem, przynajmniej na jakiś czas. A tu się okazuje, że wręcz przeciwnie. [...] Z dystansu wszystko wygląda jak kłótnia dzieciaków w piaskownicy o zabawki.

Wciąż za to oficjalnie nie wiemy, co konkretnie znaleziono w pozytywnej próbce pobranej od Wacha po listopadowej walce z Władymirem Kliczką. Całość wygląda jednak jak kabaret. Albo raczej tragikomedia ${ }^{27}$.

Autor komentarza chce udowodnić, że wydarzenia związane z Mariuszem Wachem są kpiną z profesjonalizmu. W tym celu wylicza je (dość długie wyliczenie następuje w części pominiętej w cytacie), a następnie porównuje do walki w piaskownicy, do kabaretu i tragikomedii. Powyższe porównania należy zaliczyć do sfery elocutio. Wykorzystują one wartościowanie (ośmieszają uczestników zdarzeń i podkreślają absurdalność), co ma przekonać odbiorców do racji autora (a więc do jego stwierdzenia, że dzieje się coś bardzo dziwnego i nieprofesjonalnego). Porównania pojawiające się w sferze językowej nie są dowodami, służą jedynie ich wzmocnieniu (dowodami mają być wyliczone przez autora wydarzenia: wykrycie dopingu, brak oficjalnej informacji, co wykryto, tajemnicze zniknięcie samego boksera, brak jego kontaktu z promotorem, oskarżenia w sprawie dopingu kierowane przez promotora pod adresem trenera, który unika wszystkich - w tym także dziennikarzy).

Już pobieżna analiza zebranego materiału wykazała, że zestawienia często wykorzystywane są w sportowych komentarzach prasowych jako narzędzia dowodzenia. Jak się okazało, wachlarz ich możliwych zastosowań jest szeroki, co wynika z dużego potencjału perswazyjnego. Porównywanie różnych zjawisk, obiektów czy osób może wywoływać w odbiorcach emocje, które blokują chęć weryfikacji treści przekazywanych przez nadawcę. Mamy wówczas do czynienia $\mathrm{z}$ wykorzystaniem zestawienia $\mathrm{w}$ dowodzeniu patetycznym. Inną możliwością jest użycie porównania, które odnosi się do przekonań dotyczących charakteru danej osoby (bądź grupy osób) lub do dotychczasowych działań. Takie zestawienia opierają się na mniej lub bardziej powszechnych opiniach, które ułatwiają nadawcy przekonanie odbiorców, że się nie myli. Są to przypadki zastosowania zestawień w dowodzeniu etycznym.

Niekiedy zdarza się, że zestawienia łączą różne rodzaje dowodzenia, odnoszą się do modalności i wartościowania lub osadzone są w sferze elocutio, co ma wpłynąć wzmacniająco na skuteczność fazy argumentatio. Równie interesujące

${ }^{27}$ K. Wolnicki, Boks czy kabaret?, „Przegląd Sportowy” 2013, 23.01, s. 13. 
są przypadki, gdy porównanie stanowi pomost między dowodzeniem a odpieraniem argumentów przeciwników.

Najczęściej jednak badani dziennikarze posługują się porównaniami w celu wsparcia dowodzenia pragmatycznego (logicznego). Porównanie omawianej sprawy z jednym, dwoma bądź kilkoma innymi przypadkami służy stworzeniu lub wzmocnieniu wrażenia wiarygodności wywodu autora.

\section{Bibliografia}

Błażyński L., Już nikt się nie śmieje, „Przegląd Sportowy” 2013, 29.01, s. 10.

Bogołębska B., Między literatura i publicystyka, Wydawnictwo Piktor, Łódź 2006.

Bugajski A., Mistrz Polski utkną w dziurze, „Przegląd Sportowy” 2013, 4.01, s. 2.

Bugajski A., Noworoczny plan dla kadry, „Przegląd Sportowy” 2013, 2.01, s. 14.

Burlewicz P., Będzie trudno jak nigdy, „Przegląd Sportowy” 2013, 20.02, s. 14.

Burlewicz P., Groźna ciężarówka, „Przegląd Sportowy” 2013, 4.01, s. 16.

Iwanow B., [brak tytułu], „Przegląd Sportowy” 2013, 5.02, s. 2.

Kudra A., Porównanie w poezji Stanisława Grochowiaka. Teoria chiralności i przyczynowości tropu, Wydawnictwo UŁ, Łódź 2004.

Lichański J.Z., Retoryka. Historia - teoria - praktyka, t. 1: Historia i teoria retoryki, Wydawnictwo DiG, Warszawa 2007.

Łuszczek J., [brak tytułu], „Przegląd Sportowy” 2013, 2.01, s. 2.

Rudynek G., Gdy Niemiec powie o słowo za dużo, „Przegląd Sportowy” 2013, 12.02, s. 2.

Schopenhauer A., Erystyka, czyli sztuka prowadzenia sporów, przeł. J. Lorenowicz, Wydawnictwo Verso, Kraków 2006.

Suś R., Nasza narodowa dyscyplina, „Przegląd Sportowy” 2013, 31.01, s. 2.

Szulczewski M., Publicystyka. Problemy teorii i praktyki, PWN, Warszawa 1976.

Szymanek K., Porównanie, [w:] tenże, Sztuka argumentacji. Słownik terminologiczny, Wydawnictwo Naukowe PWN, Warszawa 2008, s. 239.

Tversky A., Cechy podobieństwa, przeł. R. Balas, [w:] Psychologia poznawcza w trzech ostatnich dekadach XX wieku, red. Z. Chlewiński, Gdańskie Wydawnictwo Psychologiczne, Gdańsk 2007, s. 521-557.

Wojtak M., Gatunki prasowe, Wydawnictwo UMCS, Lublin 2004.

Wolnicki K., Boks czy kabaret?, „Przegląd Sportowy” 2013, 23.01, s. 13.

Zawisławska M., Czasowniki oznaczające percepcję wzrokowq we współczesnej polszczyźnie. Ujęcie kognitywne, Wydział Polonistyki Uniwersytetu Warszawskiego, Warszawa 2004. 
Rafał Siekiera

\section{Juxtaposition as a Tool of Argument in Sports Comment Pieces}

\section{(Summary)}

The article describes juxtaposition as a tool of argumentatio, used by sports journalists. As a powerful means of persuasion, juxtaposition can play different roles in a text. Sports journalists use juxtaposition to strengthen their arguments. As the research shows, it can form a part of various types of argument: ethical, pathetic (referring to the reader's emotions), logical and referring to modality and value judgments. Juxtaposition can also be a part of the elocutio, thus improving the effectiveness of arguments. In some examples it also plays the role of the connector between the argumentatio and refutatio.

Key words: juxtaposition, argumentatio, rhetoric. 